Publisher: Faculty of Agronomy Čačak

\title{
Fatty acid composition of rosehip seed oil
}

\author{
Dušan Vasić1 ${ }^{1}$ Dragana Paunović1 ${ }^{1}$ Bojana Špirović Trifunović1, Jelena Miladinović1,2, \\ Lazar Vujošević1, Dušica Đinović1 ${ }^{1}$ Jelena Popović-Đorđević ${ }^{*}$
}

1 University of Belgrade, Faculty of Agriculture, Belgrade, Serbia

${ }^{2}$ University of Belgrade, Institute for Multidisciplinary Research, Belgrade, Serbia

*Corresponding author: jelenadj@agrif.bg.ac.rs

Received 8 April 2020; Accepted 16 June 2020

\begin{abstract}
A B S T R A C T
Rosehip is a pseudo-fruit of the rose plant, one of the most widespread wild species of the Rosa genus in Serbia. Due to its nutritional and sensory properties, rosehip is widely utilized for the production of jams, marmalades, juices, teas, etc. On the other hand, rosehip seeds are waste material from the food industry, which represent are rich source of fatty acids. The aim of this study was to assess the fatty acids profile of rosehip seeds by applying two extraction methods: ultrasound-assisted extraction combined with organic solvent extraction (UAE/OSCE) and organic solvent conventional extraction (OSCE). The identification and quantification of fatty acids (FA), in the form of methyl esters, were performed by gas chromatography with a flame ionization detector (GC/FID). Based on the obtained results, it was observed that the composition of fatty acids and their relative amounts were influenced by the applied method, as well as by the solvent-to-sample ratio. The analysis revealed the presence of unsaturated fatty acids (UFA) as the dominant ones in most studied samples, whereas the most abundant fatty acids were, in descending order, stearic acid (48.11\%), linoleic acid (35.38\%), palmitoleic acid (33.78\%) and eicosadienoic acid $(30.57 \%)$.
\end{abstract}

Keywords: rosehip seed oil, waste material, unsaturated fatty acids, ultrasound-assisted extraction, GC-FID.

\section{И 3 В О Д}

Шипурак је псеудо-плод биљке руже, једне од најраспрострањенијих дивљих врста из рода Rosa у Србији. Захваљујући нутритивним и сензорним својствима, шипурак има широку примену у производњи џемова, мармелада, сокова, чајева итд. Семенке шипурка су отпадни материјал у прехрамбеној индустрији који представља добар извор масних киселина. Циљ овог рада био је да се процени профил масних киселина у семенкама шипурка применом две методе екстракције: ултразвучнеекстракције у комбинацији са екстракцијом органским растварачем (UZE/KEOR) и конвенционалне екстракције органским растварачем (KEOR). Идентификација масних киселина (MK), у форми метил естара, извршена је методом гасне хроматографије са пламено-јонизујућим детектором (GC/FID). На основу добијених резултата, уочено је да су примењене методе екстракције, као и однос растварача и масе узорка, имали утицај на састав масних киселина и њихову релативну обилност. Незасићене масне киселине (NMK) идентификоване су као доминантне у већини испитиваних узорака. Најзаступљеније масне киселине су биле стеаринска $(48,11 \%)$, линолна $(35,38 \%)$, палмитолеинска $(33,78 \%)$ и еикосадиеноинска киселина $(30,57 \%)$.

Кључне речи: уље семенки шипурка, отпадни материјал, незасићене масне киселине, ултразвучна екстракција, GC-FID.

\section{Introduction}

Dog rose (Rosa canina L.) is widespread in almost all of Europe, western and northern Asia and Africa, showing great adaptability to different types of soils (Mratinić and Kojić, 1998; Nowak, 2005). It grows in forests, forest glades and among shrubs, and in Serbia it can be found on Fruška gora, Kopaonik, Avala, Suva planina, Stara planina, and other mountains (Mratinić and Kojić, 1998). The fruit of dog rose, known as rosehip, has been the subject of numerous scientific studies because it contains bioactive compounds that have a positive effect on human health. Rosehip is a rich source of carotenoids, vitamins $\mathrm{C}, \mathrm{B}_{1}, \mathrm{~B}_{2}, \mathrm{~K}$ and $\mathrm{E}$, amino acids, organic acids, minerals and phenolic compounds that exhibit antioxidant, anticancer and antimutagenic properties (Szentmihalyi et al., 2002; Ercisli et al., 2007; Kilicgun and Altiner, 2010; Tumbas et al., 2012). The rosehip fruit is widely used in the food industry. Also, its potential as a component of functional food is notable due to a significant content of numerous bioactive compounds and essential elements in this pseudo fruit (Ercisli et al., 2007; Ilyasoğlu, 2014; Popović-Djordjević et al., 2020). Rosehip fruits contain $30-35 \%$ of seeds, and the content of oil in seeds may vary from 3-7 \% depending on applied extraction method (Zlatanov, 1999; Dabrowska et al., 2019). Rosehip seeds are a waste material in the food industry. Extracted seed oil contains mostly polyunsaturated fatty acids and bioactive compounds that promote skin regeneration; therefore, this oil has been used in the pharmaceutical and cosmetic industries (Zlatanov, 1999; Szentmihalyi et al., 2002; Ozcan, 2002; Concha et al., 2006).

Using different extraction methods, Zlatanov (1999), Nowak (2005), Kazaz et al. (2009), Ilyasoğlu (2017) and Javanmard et al. (2018) reported that the 
predominant fatty acids in rosehip seeds were linoleic acid and oleic acid, while Machmudah et al. (2007) found linoleic acid and stearic acid as the most abundant fatty acids in rosehip seed oil.

The ultrasound-assisted extraction method (UAE) was used as a supplementary technique for extracting oils from various seeds. This method can provide increased efficiency, better quality of the extract and reduction of the extraction time period and temperature (Cravotto et al., 2008). The possibility of lowering the extraction temperature contributes to the preservation of the extracted bioactive compounds (Yuting et al., 2013). The ultrasound-assisted extraction method requires optimization of ultrasonic power, extraction time and temperature, as well as the ratio of solvent volume to seed weight (Yuting et al., 2013). Data on the application of ultrasound-assisted extraction in the analysis of fatty acids from rosehip seed are scarce (Vasić et al., 2020).

In that respect, continuing our research in chemical characterization of rosehip from Serbia, this work aimed to determine fatty acids from rosehip seed oil, with application of UAE and OSCE methods, and using different solvent-to-sample ratios. In addition, obtained results were discussed in relation to literature data for different extraction methods.

\section{Material and methods}

Rosehip (Rosa canina L.) fruits originating from the vicinity of the town of Čačak (Republic of Serbia) were purchased at the local market (autumn 2018).

Prior to analyzing fatty acid (FA) content, rosehip samples were prepared by the following procedure: the seeds were first separated from the mesocarp of the fruit. Further, seeds were air-dried and then ground using a blender. Two methods for the extraction of fatty acids from rosehip seed oil were used: ultrasoundassisted extraction combined with organic solvent extraction (UAE/OSCE) and organic solvent conventional extraction (OSCE). Experimental conditions are given in Table 1.

Table 1

Experimental conditions

\begin{tabular}{cccccc}
\hline $\begin{array}{c}\text { Sample } \\
\text { No. }\end{array}$ & Solvent & $\begin{array}{c}\text { Solvent volume } \\
(\mathrm{ml})\end{array}$ & $\begin{array}{c}\text { Time } \\
(\mathrm{h})\end{array}$ & $\begin{array}{c}\text { Solvent to sample } \\
\text { ratio* }\end{array}$ & $\begin{array}{c}\text { Extraction method** } \\
\text { S1 }\end{array}$ \\
S2 & 2 & $1.5+68$ & $2: 1$ & UAE/ OSCE \\
S3 & 7 & $1.5+68$ & $3: 1$ & UAE/ OSCE \\
S4 & 4 & $1.5+68$ & $4: 1$ & UAE/ OSCE \\
S5 & 5 & 3 & $1.5+68$ & $5: 1$ & UAE/ OSCE \\
\hline
\end{tabular}

${ }^{*}$ - ml/g; ${ }^{* *}$ UAE - ultrasound-assisted extraction, OSCE - organic solvent conventional extraction

Ultrasound was applied to samples S1-S4 for 1.5 hours. Thereafter, samples were subjected to additional extraction (about 68 hours). Organic solvent conventional extraction (OSCE) was applied to sample S5 for 70 hours with occasional shaking. Both types of extractions were performed at room temperature $(\sim$ $\left.23^{\circ} \mathrm{C}\right)$.

After solvent evaporation, $1 \mathrm{ml}$ of hexane was added to the lipid fraction for its dissolution and better efficiency of derivatization with $14 \%$ boron trifluoride methanol reagent. To complete the derivatization reaction, the mixture was heated at $100^{\circ} \mathrm{C}$ for one hour. Fatty acid methyl esters (FAMEs) were extracted in the hexane phase after the addition of water, and then analyzed by GC-FID (Barać et al., 2018).

Fatty acid content calculated as $\mathrm{mg} / \mathrm{g}$ of lipid extract and expressed as a relative amount of total fatty acids expressed as percentages (\%) was identified by comparing with the retention times of peaks in the analytical standard mix containing 37 acids (Supelco, Bellefonte, USA).

\section{Results and discussion}

The results obtained for the fatty acid (FA) composition of the rosehip seed lipid fraction by the application of two methods are presented in Figure 1. In sample S1, no filtrate was obtained after the filtration, indicating that the solvent volume to seed weight ratio (2:1) was not suitable. In other samples, most of FAs were monounsaturated and polyunsaturated fatty acids (MUFA and PUFA, respectively), whereas only four saturated fatty acids (SFA) were identified (stearic, arachidic, heneicosanoic and behenic). 


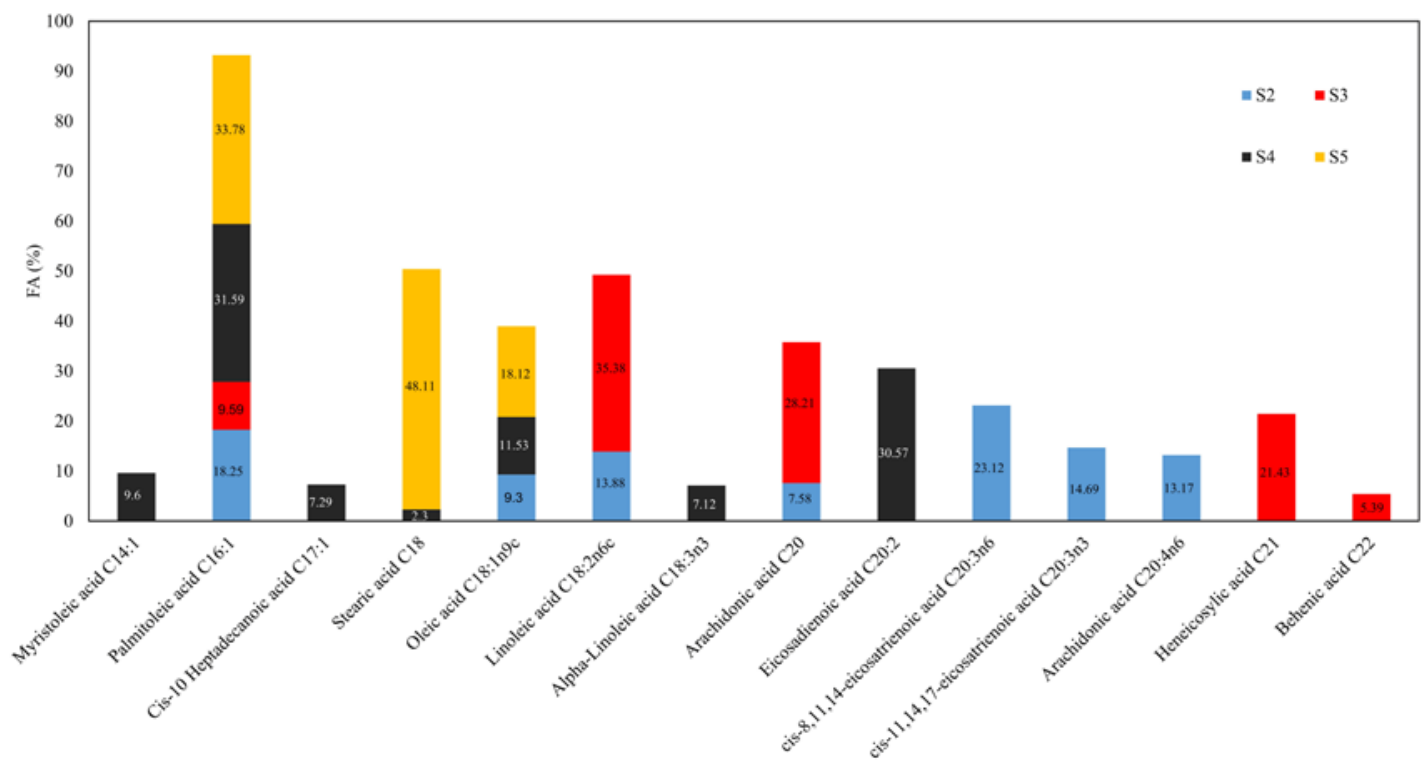

Figure 1. Content of fatty acids in samples S2-S5

In samples S2-S4, the number of identified fatty acids was significantly higher compared with sample S5, which was subjected to conventional extraction with organic solvent. Such results may indicate that the applied ultrasound-assisted extraction combined with the organic solvent extraction method was more effective than organic solvent extraction. The most abundant FA in sample S2 was cis-8,11,14eicosatrienoic acid $(23.12 \%)$, while in sample S5 stearic acid was the dominant one. Unlike other long-chain saturated fatty acids, stearic acid has no effect on cholesterol lipoprotein concentration (Yu et al., 1995). In this study, palmitoleic acid was detected in all samples (S2-S5) regardless of the applied extraction method. This acid is an omega-7 UFA, and it has been shown to have an antithrombotic effect and can be involved in prevention of stroke (Stedman, 1995; Orsavova et al., 2016). Oleic acid, detected in samples S2, S4 and S5, is an omega-9 fatty acid and it is one of the most widespread fatty acids in nature (Stedman, 1995). In this study, linoleic acid was detected in samples S2 and S3, and in sample S3 this acid was the most abundant (35.38\%). The importance of linoleic acid, the one of two essential fatty acids for humans, ch in metabolism is well documented (MacDonald, 2000). In sample S5, besides stearic acid (as the most abundant), only palmitoleic acid (33.78\%) and oleic acid $(18.12 \%)$, both belonging to unsaturated fatty acids (UFA), were identified, Figure 1.

Although samples S2 and S5 had the same S/S ratio (3:1), they differed in the number of fatty acids as well as in the fatty acids profile, which might be attributed to the extraction method. In addition, it was observed that different numbers of FAs were identified in samples extracted by UAE; seven in S2 and S4, and five in S3. In samples S2 and S4, where S/S ratios were 3:1 and $5: 1$, respectively, UFAs were the most abundant, unlike sample S3 (S/S-4:1), where SFAs predominated, Figure 2. Moreover, PUFAs were dominant acids in sample S2 (74.17\%). The differences observed in the FA profiles of samples may be associated with the S/S ratio, but also with the solvent volume used for the extraction. Namely, the highest volumes of n-heptane, $7 \mathrm{ml}$ and $5 \mathrm{ml}$, were used for the extraction of samples S2 and S4, respectively.

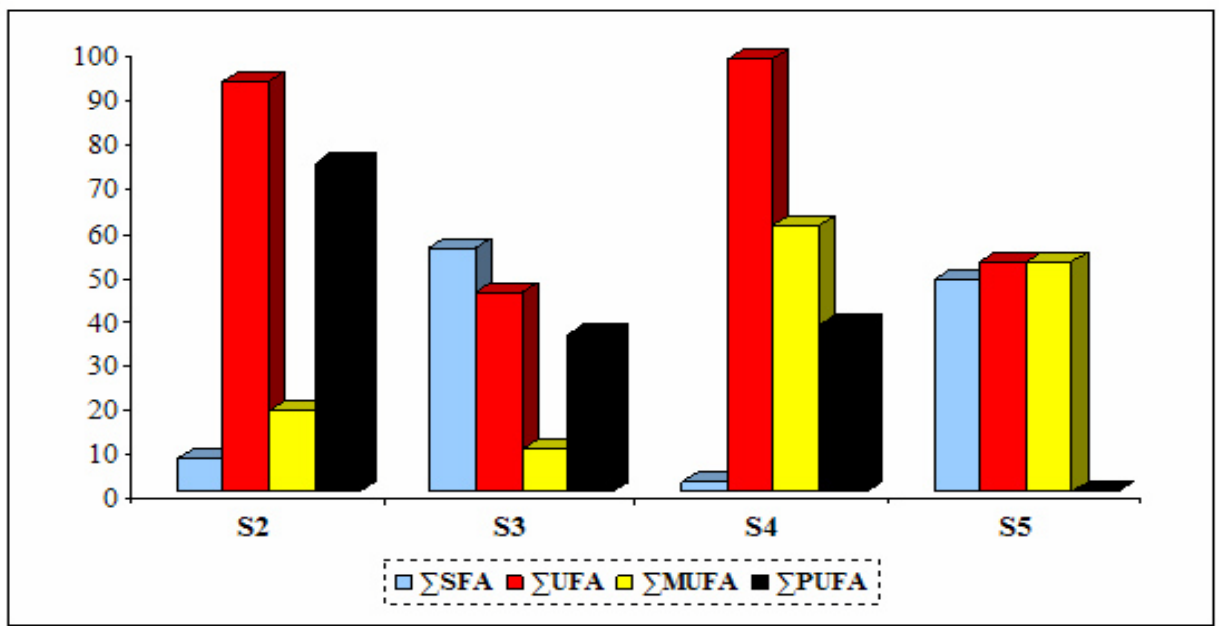

Figure 2. Fatty acids profile of samples S2-S5; saturated fatty acids (SFA), unsaturated fatty acids (UFA), monounsaturated fatty acids (MUFA) and polyunsaturated fatty acids (PUFA) 
Many studies have been conducted on the fatty acid composition of rosehip seeds using different extraction methods, and results were reported in the literature (Zlatanov, 1999; Nowak, 2005; Machmudah et al., 2007; Ercisli et al., 2007; Kazaz et al., 2009; Ilyasoğlu, 2017; Javanmard et al., 2018). Both extraction methods applied in the present research yielded palmitoleic acid, oleic acid and stearic acid. It should be noted that stearic acid was obtained by the
OSCE method in substantially higher amounts compared with the UAE/OSCE method. Linoleic and eicosadienoic acids were obtained by UAE/OSCE and OSCE methods, respectively. Stearic and linoleic acids were also obtained in seed oil using other extraction methods: Soxhlet, supercritical $\mathrm{CO}_{2}$ and Derynge, Figure 3.

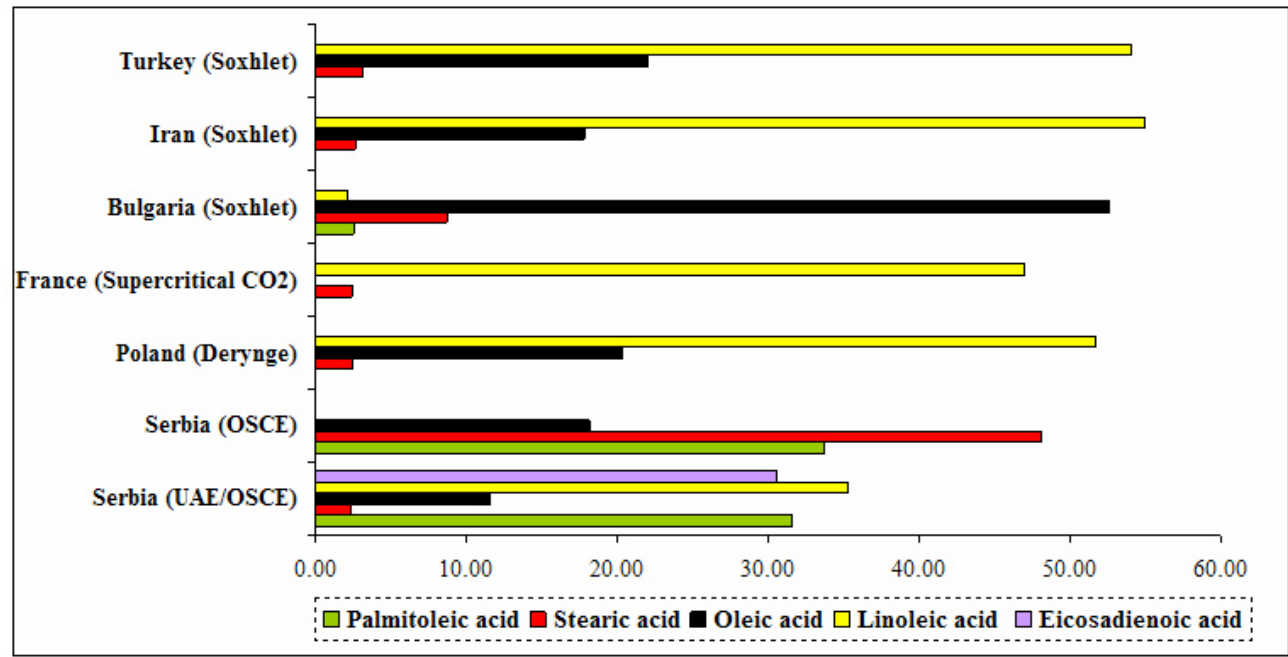

Figure 3. Comparison of data for the most abundant FAs in rosehip seed oil; literature vs. this study (Serbia)

The results of this study were compared with the literature data obtained for fatty acids in rosehip seed samples originating from different countries, Figure 3 . In the work of Nowak (2005), extraction was conducted in a Derynge apparatus and it was found that the dominant acids in rosehip seed oil from Poland were linoleic acid and oleic acid, while palmitic, stearic and cis-11,14-eicosadienoic acids were present in traces. Machmudah et al. (2007) also extracted linoleic acid and stearic acid in rosehip seed oil from France, using the supercritical $\mathrm{CO}_{2}$ extraction method Furthermore, these authors found linolenic acid, which was not identified in rosehip seed oil in this study. Kazaz et al. (2009) analyzed rosehip seed oil from Turkey using the Soxhlet extraction method; they obtained linoleic and oleic acids as the dominant acids, while stearic acid was found in smaller amounts. Zlatanov (1999), Ercisli et al. (2007), Javanmard et al. (2018) and Ilyasoğlu (2017) also used the Soxhlet extraction method. In rosehip seeds from Bulgaria oleic acid was determined in the highest concentration (Zlatanov, 1999). Javanmard et al. (2018) and Ilyasoğlu (2017) analyzed rosehip seed originating from Iran and Turkey, respectively, and found equal amounts of oleic and linoleic acids, while Ercisli et al. (2007) found linolenic acid as the predominant acid in rosehip seed oil from Turkey. Besides linoleic acid, as a dominant fatty acid, $\alpha$-linoleic acid was obtained using UAE/OSCE, but in a small amount.

The data discussed here show that differences in the composition and amount of fatty acids in rosehip seed oil may be attributed to climate, the environment and genetics factors, but also of the extraction method applied in the analysis.

\section{Conclusion}

The obtained results indicated that the extraction method, solvent-to-sample ratio, as well as the solvent volume had an effect on the composition of fatty acids and their relative amounts in rosehip seed oil. Most fatty acids were MUFAs and PUFAs, while the most abundant was stearic acid (SFA), 48.11\%. Among UFAs, linoleic acid (35.38\%), palmitoleic acid (33.78\%) and eicosadienoic acid $(30.57 \%)$ were the most dominant. The results obtained in this experiment open the possibilities for further studies on this topic.

\section{Acknowledgment}

This work resulted from research within the framework of the contract for the realization and financing of scientific research work in 2020 between the Faculty of Agriculture and the Ministry of Education, Science, and Technological development of the Republic of Serbia, registration number contract 451-03-68/2020-14/200116.

\section{References}

Barać, M., Kresojević, M., Špirović Trifunović, B., Pešić, M., Vučić, T., Kostić, A., Despotović, S. (2018). Fatty acid profiles and mineral content of Serbian traditional white brined cheeses. Traditional white brined cheeses. Mljekarstvo, 68, 37-45.

Concha, J., Soto, C., Chamy, R., Zuniga, M.E. (2006). Effect of rosehip extraction process on oil and defatted meal physicochemical properties. Journal of the American Oil Chemists Society, 83, 771-775.

Cravotto, G., Boffa, L., Mantegna, S., Perego, P., Avogadro, M., Cintas, P. (2008). Improved extraction of vegetable oils under high-intensity ultrasound and/or microwaves. Ultrasonics Sonochemistry, 15(5), 898-902.

Dabrowska, M., Maciejczyk, E., Kalemba, D. (2019). Rose hip seed oil: methods of extraction and chemical 
composition. European Journal of Lipid Science and Technology, 121(8), 1800440.

Ercisli, S. (2007). Chemical composition of fruits in some rose (Rosa spp.) species. Food Chemistry, 104(4), 1379-1384.

Ilyasoğlu, H. (2014). Characterization of rosehip (Rosa canina L.) seed and seed oil. International Journal of Food Properties, 17(7), 1591-1598.

Javanmard, M., Ali Asadi-Gharneh, H., Nikneshan, P. (2018) Characterization of biochemical traits of dog rose (Rosa canina L.) ecotypes in the central part of Iran. Natural Product Research, 32(14), 1738-1743.

Kazaz, S., Baydar, H., Erbas, S. (2009). Variations in chemical compositions of Rosa damascena Mill. and Rosa canina L fruits. Czech Journal of Food Science, 27, 178-184.

Kilicgun, H., Altiner, D. (2010). Correlation between antioxidant effect mechanisms and polyphenol content of Rosa canina. Pharmacognosy Magazine, 6, 238-241.

MacDonald, H.B. (2000). Conjugated linoleic acid and disease prevention: a review of current knowledge. Journal of the American College of Nutrition, 19, 111-118.

Machmudah, S., Kawahito, Y., Sasaki M., Goto, M. (2007). Supercritical CO2 extraction of rosehip seed oil: Fatty acids composition and process optimization. Journal of Supercritical Fluids, 41, 421-428.

Mratinić, E., Kojić, M. (1998). Samonikle vrste voćaka Srbije. Institut za istraživanja u poljoprivredi, Beograd.

Nowak R. (2005). Chemical composition of hips essential oils of some Rosa L. species. Zeitschrift fur Naturforschung, 60: $369-378$

Orsavova, J., Misurcova, L., Ambrozova, J.V., Vicha, R., Mlcek, J. (2015). Fatty acids composition of vegetable oils and its contribution to dietary energy intake and dependence of cardiovascular mortality on dietary intake of fatty acids. International Journal of Molecular Sciences, 16, 1287112890.

Ozcan, M. (2002). Nutrient composition of rose (Rosa canina L.) seed and oils. Journal of Medicinal Food, 5, 137-140.
Popović-Djordjević, J., Paunović, D., Milić, A., Krstić, Đ., Siavash Moghaddam, S., Roje, R. (2020). Multi-elemental analysis, pattern recognition techniques of wild and cultivated rosehips from Serbia, and nutritional aspect. Biological Trace Element Research, https://doi.org/10.1007/s12011-020-02199-4

Stedman, T.L. (1995). Stedman's medical dictionary. Williams \& Wilkins, Baltimore, Maryland.

Szentmihalyi, K., Vinkler, P., Lakatos, B., Illes, V., Then, M. (2002). Rose hip (Rosa canina L.) oil obtained from waste hip seeds by different extraction methods. Bioresource Technology, 82, 195-201.

Tumbas, V.T., Čanadanovic-Brunet, J.M., Četojević-Simin, D.D., Ćetković, G.S., Djilas, S.M., Gille, L. (2012). Effect of rosehip (Rosa canina L.) phytochemicals on stable free radicals and human cancer cells. Journal of the Science of Food and Agriculture, 92, 1273-1281.

Vasić, D., Paunović, D., Špirović Trifunović, B., Miladinović, J., Vujošević, L., Pećinar, I., Popović-Đorđević, J. (2020). Preliminary assessment of fatty acid profile in rosehip seeds: application of ultrasound-assisted extraction. Zbornik radova 2, XXV Savetovanje o biotehnologiji sa međunarodnim učešćem, Agronomski fakultet u Čačku, 543-548.

Yu, S., Derr J., Etherton, T.D., Kris-Etherton, P.M. (1995). Plasma cholesterol-predictive equations demonstrate that stearic acid is neutral and monounsaturated fatty acids are hypocholesterolemic. The American Journal of Clinical Nutrition, 61, 1129-1139.

Yuting, T., Zhenbo, X., Baodong, Z., Martin, Y.L. (2013). Optimization of ultrasonic-assisted extraction of pomegranate (Punica granatum L.) seed oil. Ultrasonics Sonochemistry, 20, 202-208.

Zlatanov, M.D. (1999). Lipid composition of Bulgarian chokeberry, black currant and rose hip seed oils. Journal of the Science of Food and Agriculture, 79(12), 16201624. 